\title{
The Importance of Compassion as the Default in Times of Crisis: The Curious Case of "Vertical Interdiction"
}

\author{
Tara Lagu, MD, MPH
}

Institute for Healthcare Delivery and Population Science at the University of Massachusetts Medical School at Baystate Health, Springfield, Massachusetts; Department of Medicine, University of Massachusetts Medical School at Baystate Health, Springfield, Massachusetts.

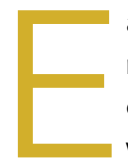

ach night, while my 2-year-old is having her dinner of macaroni and cheese or chicken nuggets, we video chat with my elderly parents. It used to be that this time was mainly my daughter showing off her newfound fork skills, but lately it has become "elderly parent education hour."

"Well, we're trying to decide if we should go to the bridge club," announced my mother early in the week of March 13th.

"No, mom! Under no circumstances should you go to the bridge club! Social distance! Stay home! If I've given up restaurants and babysitters and am sitting here every night holding a phone covered in mac and cheese grease, you can give up the bridge club!"

I am all for keeping my elderly parents as isolated as possible during these pandemic times. I wasn't alone in my fear that they weren't taking my advice seriously: My social media feed was subsequently filled with posts from other physicians who had also been educating their parents about the need for social distancing.

\section{ECONOMIC FEARS AND POLICY PROPOSALS}

Then, just as we were all settling into "social distancing," on March 20, a debate emerged on the opinion pages of The New York Times that took the argument to the next level: A former professor of mine suggested a move from a policy of "horizontal interdiction" (one that restricts the movement of the entire population, without taking risk into consideration) to a "vertical interdiction" strategy that focuses on sequestering those among us most likely to experience poor outcomes from coronavirus infection (eg, the elderly, people with chronic diseases, and the immunologically compromised). ${ }^{1}$

This first piece was followed 2 days later on March 22 by an article from a regular New York Times contributor who called social distancing "groupthink" and then seconded the vertical interdiction proposal. ${ }^{2}$ Both pieces referred to the downturn in the economy as the reason the policy would be an improvement on social distancing; they argued that lost jobs and services would cause less suffering and loss than a policy that required extended isolation of the elderly.

Corresponding Author: Tara Lagu, MD, MPH; Email: tara.lagu@bhs.org; Telephone: 413-794-7688; Twitter: @taralagumd.

Published online first April 20, 2020.

Received: April 2, 2020; Accepted: April 3, 2020

(๐) 2020 Society of Hospital Medicine DOI 10.12788/jhm.3428

\section{NOT A FEASIBLE OPTION}

On closer inspection, however, vertical interdiction is different and much scarier than "social distancing." The words used by the author of the original article gave a clue: "If we were to focus on the especially vulnerable, there would be resources to keep them at home, provide them with needed services and coronavirus testing, and direct our medical system to their early care. I would favor proactive rather than reactive testing." This was not just a plan to keep my parents from the bridge club. This was a plan for forced quarantine, mandatory testing, and months of isolation. Almost immediately, physicians and policy makers identified feasibility problems with the idea. ${ }^{3}$ To name a few, it is not clear that the death rate in young people is all that low; even with removing elders from the equation, the demand for hospital and critical care services is rapidly overwhelming supply; testing the "herd immunity" hypothesis in real time with a virus that has a death rate of $1 \%-3 \%$ still runs the risk of causing millions of deaths.

I will add a few more reasons why this idea of vertical interdiction was never feasible: There is no existing structure to facilitate mandatory isolation and quarantine of elders. We have no mechanism for caring for elders who are isolated at home. We cannot rapidly design the digital health monitoring needed. We cannot provide the mobile testing proposed. In the case of seniors who require nursing care, the problems would be even greater. Our recent efforts to protect patients in nursing facilities have proven to be extremely difficult. The greatest problem is finding a way to keep the staff from bringing the virus into the facility (and there are many staff: nutrition services, nursing, patient care technicians, physical therapy, social work). The only possible answer to this issue might mean wearing extensive protective equipment, similar to physicians in Wuhan ${ }^{4}$ (full-head hood plus goggles). Imagine being a patient in this scenario: months of being bathed, dressed, fed, and helped to the bathroom by a person in an isolation suit.

\section{A CRITICAL NEED TO MAINTAIN A DEFAULT OF COMPASSION}

Now, just a few weeks later, with the virus spreading and many nonelders on ventilators, the idea of "elderly sequestration" as it was presented in mid-March feels dated and irrelevant. However, the episode can and should teach us a more important lesson: The idea was fatally flawed not only because it was not feasible but primarily because it was so lacking in compassion. 
The lack of compassion was not just related to the fact that patients with end-stage dementia will undoubtedly be confused and frightened when confronted with months of care administered by people in hazmat suits. It is also that the proposed policy, by creating pockets of isolation, felt like a setup for missteps and subsequent rampant infection. My first thought was that these policies would not protect vulnerable elders but hide them from view, causing another situation like the one at Lifecare in Kirkland, Washington, which resulted in more than 35 deaths. ${ }^{5}$ This time, our policies (and not just our carelessness) would be responsible for creating it.

While writing this article, sadly, such a thing has happened, just miles from my home. The Soldiers Home in Holyoke, Massachusetts, is a skilled nursing facility that has generally been very highly regarded by veterans and their families. Unfortunately, a lack of responsiveness to the current pandemic, including failure to provide protective equipment, failure to remove symptomatic staff from frontline care, and a lack of transparency about symptomatic staff and patients has resulted in a scandal and a tragedy. ${ }^{6}$ Over 5 days at the end of March, eight veterans died of coronavirus without patients being sent to hospitals and without the cases being reported to either Massachusetts or local officials. Many other patients in the facility also tested positive for coronavirus, as did staff members. While this incident was not driven by a vertical interdiction policy, it was the result of actions taken to isolate and sequester elders from the community. The worst (and most symbolic) injustice was the fact that, because of rules about disposing of bodies with coronavirus (and possibly to cover up the incompetence that led to the deaths), the bodies of deceased veterans were piled into a refrigeration truck sitting in the parking lot of the facility as the tragedy unfolded.

This is a defining moment for physicians, for the healthcare system, and for our society. I am so proud of my colleagues who have stepped up, shown up, worn their (sometimes improvised) personal protective equipment and kept seeing pa- tients because it is our job and it is part of the contract we entered into when we became physicians. Our policy choices in this moment are just as important, and it is not our ability to "get the economy started again" but our sacrifices now (or lack thereof) that will be remembered for a hundred years. Choosing patients over profit, compassion over callousness, are important not just for controlling hospital volumes and reserving intensive care unit beds, but also for preserving our professional integrity and saving our humanity.

Disclosures: The author reports grants from the National Heart, Lung, and Blood Institute of the National Institutes of Health under Award R01 HL13998501A1 and 1R01HL146884-01 and personal fees from the Yale Center for Outcomes Research and Evaluation under contract to the Centers for Medicare and Medicaid Services.

\section{References}

1. Katz DL. Is our fight against coronavirus worse than the disease? New York Times. March 20, 2020. https://www.nytimes.com/2020/03/20/opinion/coronavirus-pandemic-social-distancing.html. Accessed April 3, 2020.

2. Friedman TL. A plan to get America back to work. New York Times. March 22, 2020. https://www.nytimes.com/2020/03/22/opinion/coronavirus-economy.html. Accessed April 3, 2020

3. Apkon M, Forman HP, Sonnenfeld J. Why isolating older Americans would be a huge mistake in fighting the coronavirus. Fortune. March 24, 2020. https:// fortune.com/2020/03/24/coronavirus-curve-herd-immunity-deaths/?fbclid=IwAROK3_40MDmwrP4djtqkcAZBXFaJVilv1_2GGgZBQ269oLcTkJmptuR5G00. Accessed April 3, 2020

4. Gawande A. Keeping the coronavirus from infecting health-care workers. New Yorker. March 21, 2020. https://www.newyorker.com/news/news-desk/ keeping-the-coronavirus-from-infecting-health-care-workers. Accessed April 3, 2020.

5. Read R. Nursing home staff spread coronavirus to other facilities, CDC investigation finds. Los Angeles Times. March 18, 2020. https://www.latimes. $\mathrm{com} /$ world-nation/story/2020-03-18/coronavirus-spread-nursing-homes. Accessed April 3, 2020.

6. Christensen D. 'Just complete chaos': Soldiers' Home staff cite dangerous conditions fueling COVID-19 outbreak. Daily Hampshire Gazette. March 31, 2020. https://www.gazettenet.com/Employees-allege-laxCOVID-19-safety-protocols-at-Holyoke-Soldiers-Home-33631412. Accessed April 3, 2020. 